\title{
淡塩二成層からの表層取水における混合効果 THE EFFECT OF MIXING FOR SELECTIVE WITHDRAWAL FROM A FRESH-SALT WATER SYSTEM
}

\author{
北海道大学 正会員 ○吉田 静男
}

塚田昌司

\section{1.はじめに}

表層取水の問題は、水平に流れている密度成層流が何らかの構造物を越える直前までの流れ構造を明らかに するそれと同じである。構造物を越えた後の流れの問題としては lee wave があげられる。この両者の流れ 場を支配する方程式は、U $w$ ををれぞれ主流方向 $(x)$ 、及び、鉛直方向 $(z)$ の流速成分とし、非粘性を仮定すれ ば次式で与えられる。

$$
\frac{d^{2} \tilde{\Psi}}{d x^{2}}+\frac{d^{2} \tilde{\Psi}}{d z^{2}}+\frac{g z}{\rho_{s}} \frac{d \rho}{d \tilde{\Psi}}=\frac{1}{\rho_{s}} \frac{d H}{d \tilde{\Psi}}=f(\tilde{\Psi})
$$

ここで $\rho$ は密度、 $\rho_{s}$ は基準の位置での密度、 $\left(\rho / \rho_{s}\right)^{1 / 2} u=\partial \tilde{\Psi} / \partial z,\left(\rho / \rho_{s}\right)^{1 / 2} w=\partial \tilde{\Psi} / \partial x, H=\mathrm{p}+\left(u^{2}+w^{2}\right) / 2+$ $\rho g z$ である。(1)式は $\mathrm{Yih}^{1)}$ によって導出されたものであるが、彼は、さらに $d \rho / d \tilde{\Psi}$ と $d H / d \tilde{\Psi}$ が $\tilde{\Psi}$ の一次式 で与えられる場合の解析を行ない、これを底部 line sink の場合にあてはめた。この場合の支配方程式は次式 で表現できる。

$$
\frac{d^{2} \Psi}{d \xi^{2}}+\frac{d^{2} \Psi}{d \zeta^{2}}-F^{-2} \zeta=-F^{-2} \Psi
$$

ここで $F=U / d \sqrt{\beta, g}, U=\sqrt{\rho / \rho_{0}} U^{\prime}, \xi=x / d, \zeta=z / d, \Psi=\tilde{\Psi} / U d, \rho=\rho_{0}(1-\beta y), \beta=\left(\rho_{0}-\rho_{1}\right) / \rho_{0} d, \rho_{0}, \rho_{1}$ は水底 及び水表面での密度, $d$ は全水深, $g$ は重力加速度, $U^{\prime}$ は上流遠方での $x$ 方向流速である。Yihは(2)式の解の 形式から $F \leqq 1 / \pi \doteqdot 0.318)$ において sink 上部によどみ領域が発生し、流動層との間に dividing line が発

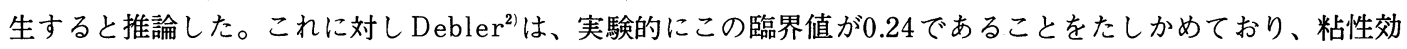
果を考慮するならば、Yihの理論結果は、ほぼ立証されたといってよい。

我が国では、大西・日野) が(2)式を軸対称の成層流にまで拡張し、吸込高さによる流れ構造を解析した。吉 田) は彼らの模型実験における取水時間がきわめて短いことに注目し、取水時間が長くなることによって何ら かの混合効果が生じるのではないかと考光、以下の検討を行なった。

まず、長時間取水を可能ならしめるため、塩水の上に淡水を流し、せきを用いて表層を取水した。仅に、混 合が無視できるとしたなら、流線に沿って(1)式中の $H$ が一定となるから、水表面、及び、界面において次式が 成立するはずである。

$$
\begin{aligned}
& \text { 水表面 } \frac{q_{s}^{2}}{2}-\frac{U_{s}^{\prime 2}}{2}=g\left\{h_{\infty}-\left(h_{1}+h_{2}\right)\right\} \\
& \text { 界 面 } \frac{q_{i}^{2}}{2}-\frac{U_{i}^{\prime 2}}{2}=\varepsilon g\left(h_{2}-h_{\infty}\right)
\end{aligned}
$$

ここに $q^{2}=u^{2}+v^{2}, h$ は水梁, $\varepsilon=\left(\rho_{2}-\rho_{1}\right) / \rho_{2}, \rho$ は密度, 添字 1,2 は上, 下層、 $i, s$ は界, 表面、 $h_{\infty}$ は $x=\infty$ における全水深である。(3)式右辺は水表面の降下量に $g$ をかけたものであり、(4)式右辺は界面の上昇量に $\varepsilon g$ をかけたものと見ることができる。(3)式を使用して実験結果との比較を行なう場合、水表面の降下量があまり にも小さすぎて解析が困難である。そこで、(4)式と実験結果を比較すると図ー 1 に示す結果を得る。図ー 1 の 結果は $q_{i}$ のかわりに断面内の最大流速值を用いて得られているが、それでも(4)式は、現実の界面よりはるか下 方に位置する dividing lineしか与えない。

この結果から、ただちに混合効果の存在を認めることはできないが、とにかく理想流体の結果をそのまま適 用し得ないことは明白である。同様のことは、現実のダム取水の場合のように長時間取水し続ける場合にもお 
こりうることが予想された。事実、柏村ら ${ }^{5)}$ が上述の大西・日野の解析手法をダムの取水塔近傍に適用したと ころ、吉田の実験結果と同じ傾向、すなわち、予測される dividing line が現実のものに比べてはるかに低い ことが明らかにされた。その後、吉田6 は、一連の実験を通じて、上述の実験結果に関しては、混合によっ て生じた中間密度層が diving line を押し上げる結果となっていることをつきとめた。中間密度層は、勿論、

混合を無視しては考えられない存在であり、かくして、取水に対する混合効果の存在は明白となった。ここで は、この中間密度層の水理特性、及び、その形成維持機構についてのべることにする。

\section{2. 中間密度首の水理特性}

本節では、巨視的な中間密度層の特性についてのべる。 今、一端にせきを有し他端が閉じられた $15 \mathrm{~cm} \times 20 \mathrm{~cm}$ の矩形 断面を有する長さ $300 \mathrm{~cm}$ 直線水路を水平におき、あらか じめ、塩水を $3.0 \mathrm{~cm}$ の深さだけためておく。次に、混合を できるだけおさえる方法で淡水をこの塩水の上に重ね、せ きを越流させて取水すると、2 時間後には図一 2 に示すよ うな流速ならびに密度分布を得る。なお、密度分布は白金 電極とガラスサーミスターの対になった素子を用いて測定 し、流速分布は図一 3 に示す系からなる LDV を用いて測

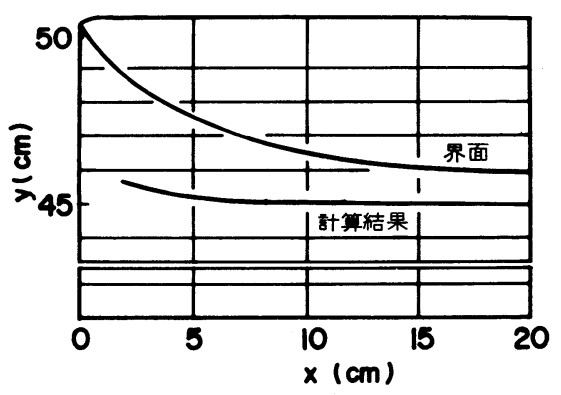

図-1 れている。このときの取水開始寸前の密度分布は図ー4に示されている。図ー 2 には明らかに中間密度層か認 められ、図一 4 との比較から、この層が取水後に形成されたものであることが分かる。この事実は、同時に、 中間密度層が時間の経過とともに成長するものであることを示唆しているが、その様子を見るために中間密度 層の時間的成長を追ってみると図一 5 のごとくである。なお、この場合の使用水路は $8 \mathrm{~cm} \times 15 \mathrm{~cm} \times 700 \mathrm{~cm}$ であ る。この成長過程を見ると、中間密度層内の成層状態の変化が落着くまでに 2 時間程度必要であることが分か る。勿論この傾向は、流れの規模によって様々に変わることが予想されるが、この点を検討するため、せきか

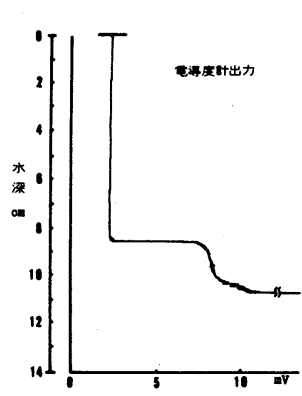

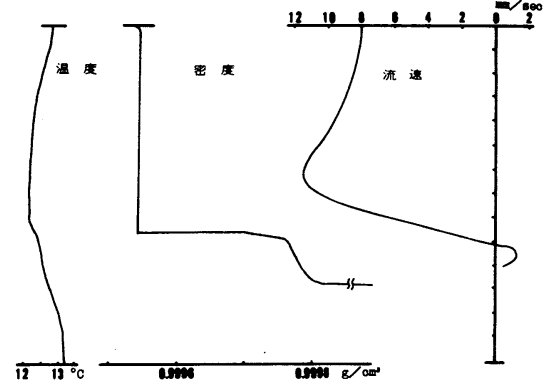

図-2

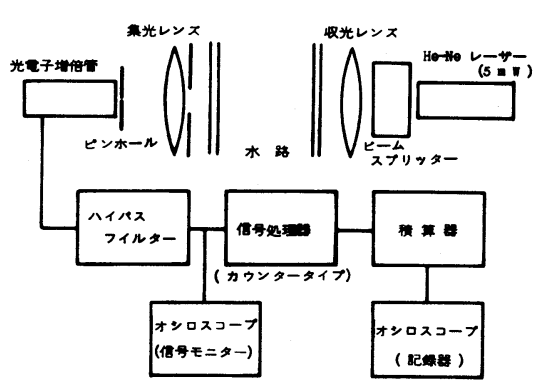

困-3

$560 \mathrm{~cm}$ 離れた位置での中間層と淡水層との境界を時間的に追ってみると図 -6 の結果を得る。この結果は先の例より流動層が厚い場合のもので、定常化する に要する時間もかなり長くなっている。一方、中間密度層内の密度を調べると 図一 7 が示すように、取水量の増加につれて全体的に高くなってゆくことが分 かる。これに対し、取水量を一定とし、下層の密度を変化させた場合の中間密 度層内の密度構造は、図一 8 が示すようにあまり変化しない。

ここで内部フルード数の分布を調べておこう。勿論、最下層の密度を下層密 度として採用できない故、中間層内の平均密度をもってこれにかえると図 -9 の結果を得る。これより、せきのごく近傍で内部フルード数が 1 になることは

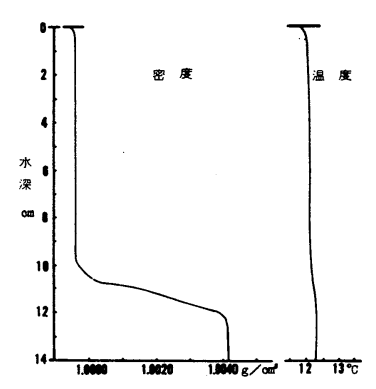

図-4 

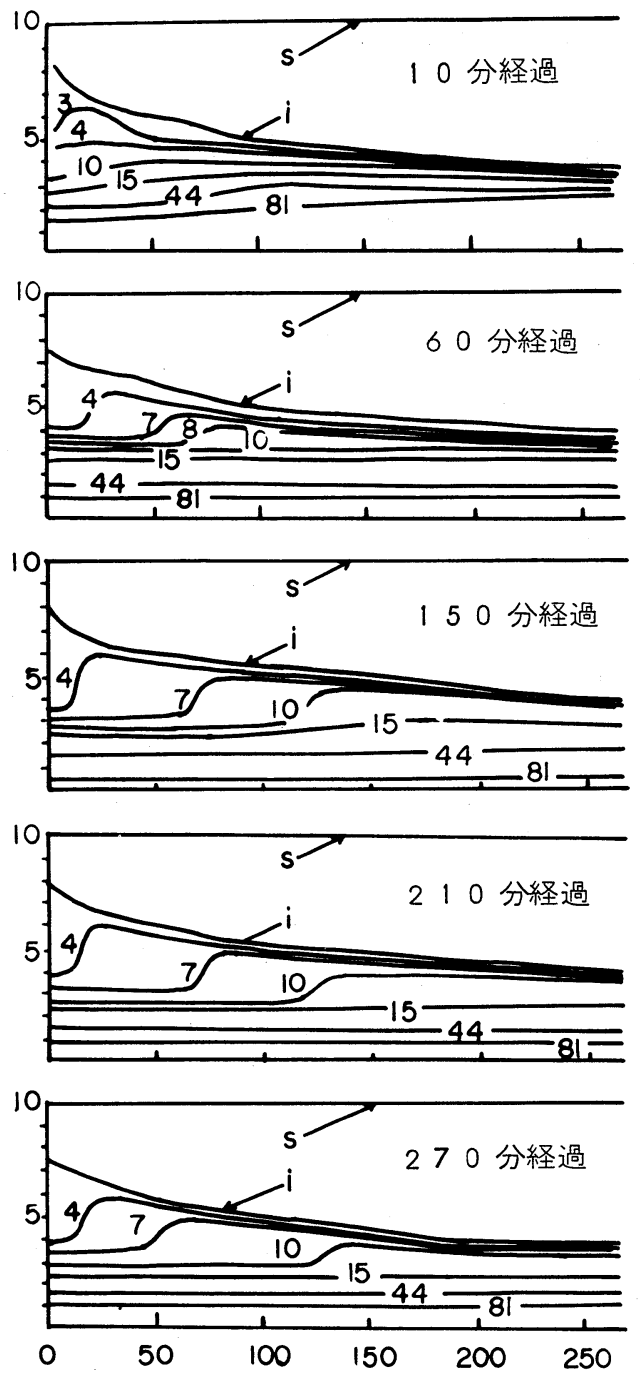

図一 5 図中横軸はせきからの距離 $(x \mathrm{~cm})$ 縦軸は水 位 $(y \mathrm{~cm}), s, i$ は表, 界面を示す。罒中の数值を $n$ と すれば、密度 $\rho$ は次式で与えられる。

$$
\rho=(9992+n) \times 10^{-4} \mathrm{~g} / \mathrm{cm}^{3}
$$

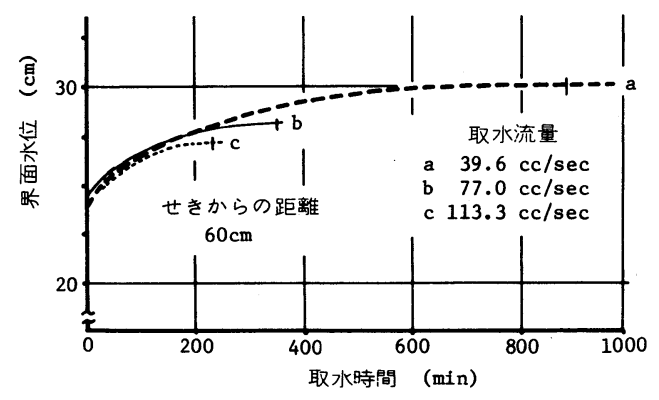

困一 6
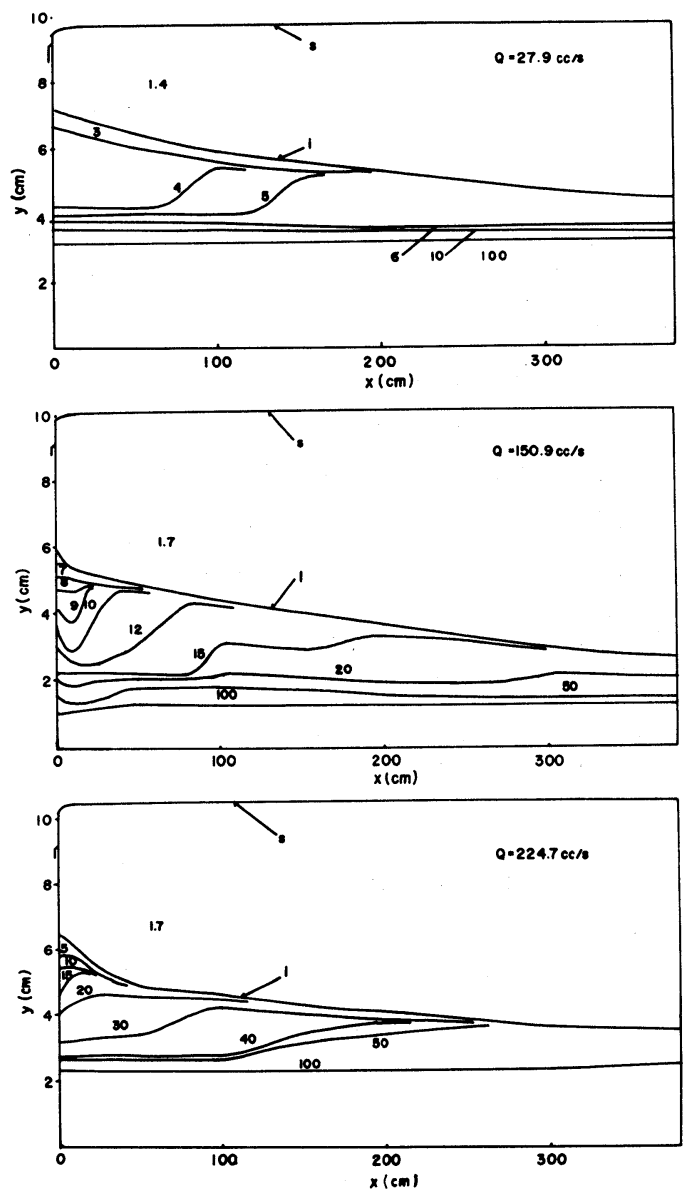

困一 7
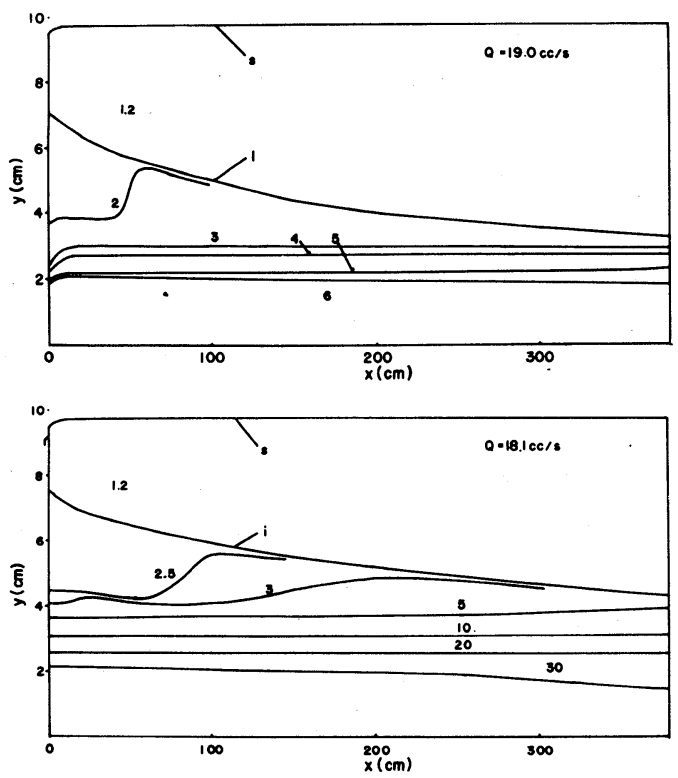

困-8 
明白である。ただ、細部を検討すると、界面に波動 を生じない取水量 $(30 \mathrm{cc} / \mathrm{sec})$ のもとではせきの位 置でも 1 に達していない。この理由が中間密度層の 未発達にもとずくものかどうか、今のところ不明で ある。

以上の結果を総合すると、中間密度層の水理特性 が塩水楔のそれとよく似ていることが分かる。この ことから、 dividing line の形成は、非粘性的に生じた ものではなく、界面抵抗が関係しているのではない かという予想が立つ。この予想が正しいかどうかは、 界面抵抗係数 $f_{i}$ と $\Psi\left(\theta^{-3}, \theta\right.$ はKeulegan数 $)$ との関係 を、塩水楔のそれと比較することにより判断できる。 中間密度層のように鉛直ならびに水平方向に密度が 分布している場合の. $f_{i}$ は近似的に次式で与えられる。

$$
\begin{aligned}
& f_{i}=-\frac{2 g}{U_{1}\left|U_{1}\right|}\left(\frac{h_{1} h_{2}}{h_{1}+h_{2}}\right)\left(\frac{\partial h_{1}}{\partial x}\left(\varepsilon-\frac{U_{1}{ }^{2}}{g h_{1}}\right)-\frac{h_{2}}{2 \rho_{2 m}}\right. \\
& \left.\frac{\partial \rho_{2 m}}{\partial x}\right\}
\end{aligned}
$$

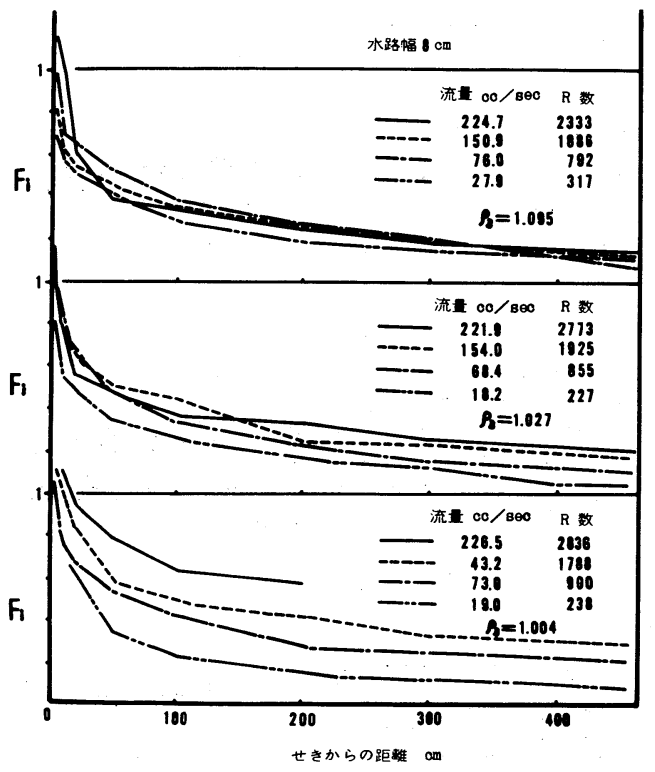

図- 9

ここで $x$ は水平方向上流に向かってとった座標、 $h_{1.2}$ は淡水及び中間層の厚さ、 $U_{1}$ は淡水平均流速、 $g$ は重力 加速度、 $\rho_{2 m}$ は中間層鉛直断面の平均密度である。(5)式を用いて実際に $f_{i}, \Psi$ の関係を求めると図一10のごとくで、 筆者の一人 ${ }^{7}$ が提案した $f_{i}=0.25 \Psi^{-0.5}$ の延長線上に分布する。ただ、塩水楔の場合と同様、 $\psi$ の係数 0.25 は $0.2 \sim 0.35$ の範囲であれば何を採用してもよい程のバラッキを有している。以上のことから、中間密度層の形 状 (dividing line) 維持には塩水楔のそれと同じ原因、すなわち（厳密な証明はなされていないが、多くの研究者 が信じている）界面抵抗にもとずいているといえる。

さて、中間密度層が、塩水楔とほぼ同様の水理特 性を有しているということは、取水流量がきわめて 大なるときに、中間密度層が消滅することを暗示し ている。これは事実であって、その場合でも、せき 近傍の内部フルード数はほぼ 1 の值を保持している。 勿論、このときの下層密度としては最下層の平均密 度を採用しており、dividing lineは、取水前の界面に 一致することになる。かくして、今度は、下層塩水 が塩水楔の形状特性を示し、いたるところで内部フ

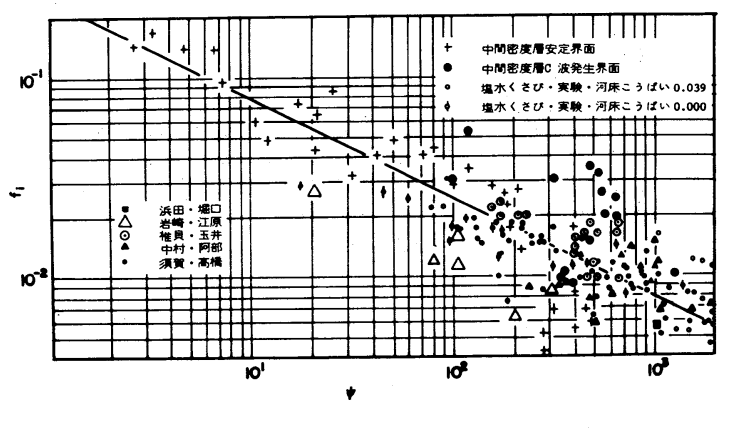

図 -10

\section{こえて流出する結果となる。}

\section{3. 取水中への塩分混入機構}

取水条件によっては、取水中の塩分量がせきを越える寸前の淡水中の塩分量よりはるかに多い場合がある。 たとえば、表ー 1 が示すように、下層密度にはあまり関係せずに、取水量の増加に伴って、この特徴が明確に 現われる。この意味するところは、取水中の塩分のすべてが界面を通じて淡水層内に拡散したものではないと いうことであり、中間層の塩水が直接、せきを越流する機構も存在するということである。この機構としては、 現在のところ $2 つ$ 存在することが分かっている。いずれも定常流の場合であるが、1つは界面波の山がせきを 越えるタイプで、せきのほぼ中央で見出され、他は側壁近くでせきを越える連続流出タイプである。前者につ いてはすでに報告していることでもあるので、ここでは後者のタイプについでのみふれておく。後者の塩水流 
出機構を知るには、まず、 表 -1 せき近傍の流れを調べる必 要がある。未だ完全な把握 には至っていないが、せき 近傍での微細な流れ構造は およそ、次のとうりである。 前節に述べた $\psi$ 値が 500 を かなり下まわるときは、 dividing line 上の淡水流 れはポテンシャル流に近い 流線を有している。しかし、 $\Psi$ 值が 500 程度になると、 せきから遠い界面では、サ イクロイド波泉を生じ、せ

\begin{tabular}{|c|c|c|c|c|c|}
\hline Run & $\begin{array}{l}\text { 下層密度 } \\
\left(\mathrm{g} / \mathrm{cm}^{3}\right)\end{array}$ & 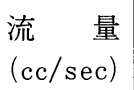 & $\begin{array}{l}\text { 取水中の塩分 } \\
\text { 混入率 }(g / \ell)\end{array}$ & $\begin{array}{l}x=2 \mathrm{~cm} \text { での淡水内 } \\
\text { 塩分混入率 }(\mathrm{g} / \mathrm{l} \ell)\end{array}$ & $\begin{array}{c}\text { 水 温 } \\
\left({ }^{\circ} \mathrm{C}\right)\end{array}$ \\
\hline 1 & 1.0040 & 19.0 & 0.029 & 0.023 & 15.3 \\
\hline 2 & 1.0039 & 72.0 & 0.034 & 0.013 & 13.6 \\
\hline 3 & 1.0040 & 143.2 & $0.045 \sim 0.052$ & 0.022 & 12.6 \\
\hline 4 & 1.0040 & 226.9 & $0.085 \sim 0.090$ & 0.020 & 12.2 \\
\hline 5 & 1.0104 & 19.8 & $0.030 \sim 0.034$ & 0.023 & 16.1 \\
\hline 6 & 1.0104 & 70.9 & 0.042 & 0.026 & 14.2 \\
\hline 7 & 1.0104 & 148.0 & 0.040 & 0.022 & 12.8 \\
\hline 8 & 1.0104 & 225.0 & $0.062 \sim 0.079$ & 0.019 & 12.5 \\
\hline 9 & 1.0284 & 221.9 & $0.048 \sim 0.055$ & 0.007 & 12.7 \\
\hline
\end{tabular}
き近傍では、淡水内に、写 真一 1 に示す回転流が見出されるようになる（ただし $\Psi$ 值につい ては本研究で用いた規模の水路にしかあてはまらない)。この回転 流の流線を追跡してみると、写真一 2 に示されるU字型のvortex filament を形成しており、filament は両側壁に近いせきを越え て流出している。一方、中間密度層は常にこの filament に隣接 しており、流心におけるせき直下では filament の存在のために、 くぼむ形を強いられる。そして、界面波によって時おり攪乱され るごとに、この filament に塩水が連行され、U字型の vortex filament 内の流線に沿って輸送される（写真一 1 にこの連行の 様子がタイミングよくとらえられている)。この輸送機構は、むし ろ、間けつ的であり、刻々作り出される中間層内の希釈塩水が連 続的にせきを越流する機構は別にある。それは、U字型 vortex に隣接する中間層自体がvortex filament (写真-3）を形成し 側壁近くのせきを流出する機構である。写真一 4 には、このよう な filament が 2 本存在する例がとらえられている。なお、この 写真は、せき近傍の水表面と界面のほぼ間位置における水平断 層写真である。

以上のことから、中間密度層の形状の維持機構が明らかとなる。 すなわち、何らかの 機構によって刻々生 成される希釈塩水が 中間層の界面を押し 上げ、せきの位置に おける内部フルード 数が 1 を上まわるこ とがあれば、上述の 機構を通じて過剩な

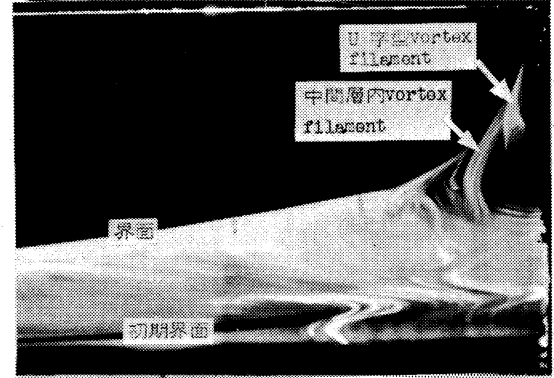

写真 -3 流れに沿う鉛直面の断層写真

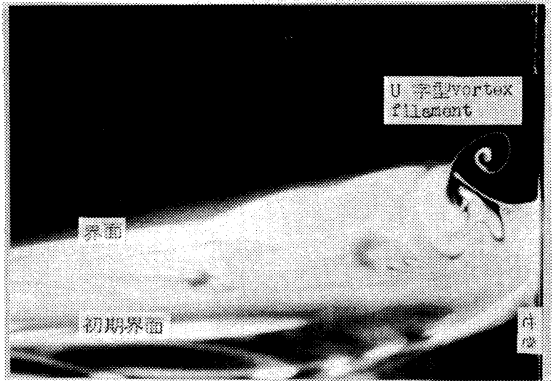

写真－1＼cjkstart流れに沿う鉛直面の断層写真

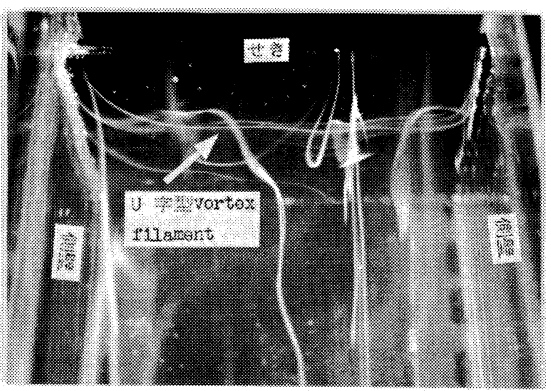

写真-2 U字型vortex filament

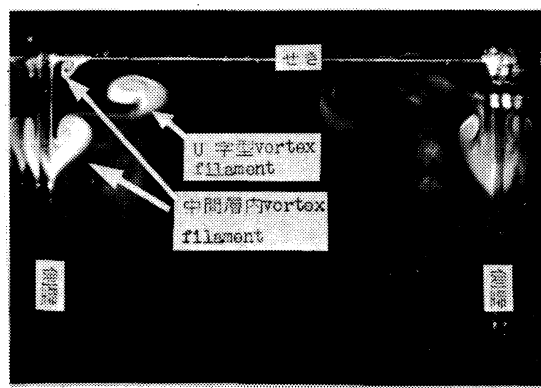

写真 -4 水平面の断層写真 
塩水が排除されるのである。

\section{4. 中間密度層の形成機構}

中間層の形成には、主として、縦渦と、サイクロイド波直下のスパイラル渦、そして淡水流れにひきずられ る流れとそれによって失なわれる体積を補なう counter flow が寄与している。このうち渦は中間層内に淡水 及び塩水を連行し、二次流は、それによって生じた新たな密度構造の流体を水平方向に輸送する役目を主とし てになっている。紙面の関係で詳細な議論はできないが、図一11の流れ図を用いれば、もう少し立入った機構 の説明ができる。まず、淡水輸送経路から述べよう。淡水は、縦渦とサイクロイド波直下のスパイラル渦、そ して上には述べなかったが、前節で述べたU字渦に接する中間層内に生ずる vortex filament の連行作用によ り、中間層内に輸送される。その量はせきに近い剪断流の強いところほど多く、上流に向かうにつれて漸減す る。ここで注意すべき点は、サイクロイド波直下のスパイラルの鉛直方向の径に比べて、縦渦のそれは大きく、 中間層の厚さにほぼ一致していることである。すなわち、サイクロイド波直下のスパイラルは淡水を中間層に 輸送するものの、その淡水が dividing line 下、わずかの水深にとどまるのに対し、縦渦による輸送は中間層 底部にまで及んでいる。一方、下層の塩水は主として縦渦の連行作用によって中間層内に輸送される。この他、 せき近傍では、二次流の counter flow の剪断流不安定にもとづ き下層から塩水を連行する場合もあるが、これについては無視し 得る程度であると考えている。なお、縦渦は塩水楔のそれとまっ たく同じ流れ構造を有しており、年真一 5 に示すように、一対の 渦からなっている。写真一 6 にはサイクロイド波の平面的な形状 がとらえられているが (白い部分が山)、この写真が示すように、 縦渦により生じた谷から発して側壁に向かうに従って振幅が小さ くなるのが普通である。以上のような機構を通じ、せきに近いほ ど淡水混入量の多い、塩水楔とは密度分布の傾向が逆な中間密度

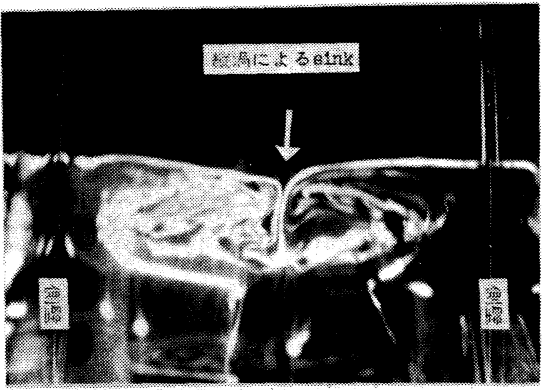
写真 -5 たて渦

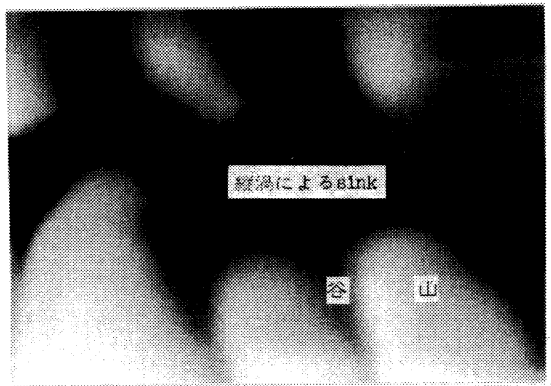

5 ) 柏村ほか：石狩川の流出解析と流砂に関する研究, 北大 委託研究, pp. 120-131, 1973.

6 ) 吉田 - 北越 - 福田: 土木学会北海道支部論文報告集, 30 , pp. $97-100,1974$.

7 ) 吉田: 年講, 29, pp. $425-426,1974$.

8 ) 吉田: 土木学会北海道支部論文報告集, $31, \mathrm{pp} .195-198$, $198,1975$.

9 ) 吉田: 土木学会論文報告集, 273, pp. 59-68, 1978.

10）吉田 ·田城 - 西田: 海工論文集, 26, pp. 554-558, 1979.
写真一 6 サイクロイド波

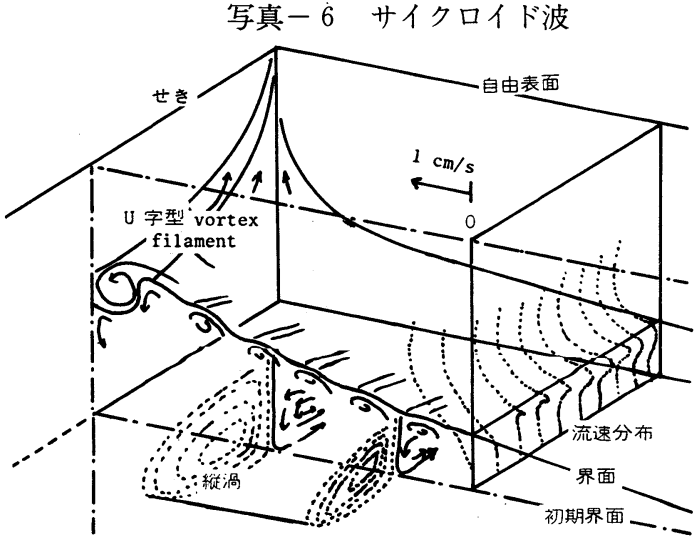

困-11 中間層内の流れ構造 